\title{
PENGARUH DIAGRAM VENN DAN RELASI DALAM MENINGKATKAN PEMAHAMAN SISTEM BASIS DATA
}

\author{
Lin Suciani Astuti ${ }^{1}$, Siti Julaeha ${ }^{2}$ \\ Program Studi Teknik Informatika, Universitas Indraprasta PGRI \\ Email: elinsuciaja@gmail.com ${ }^{1}$
}

\begin{abstract}
Abstrak
Tujuan dengan diadakannya penelitian ini adalah meningkatkan pemahaman sistem basis data dengan menggunakan diagram Venn dan diagram relasi. Tahapan penelitian yang pertama yaitu dengan melakukan pretest yang berisi materi, soal dan penyelesaiannya menggunakan diagram Venn dan diagram relasi. Tahapan posttest dengan cara yang sama agar dapat dilihat peningkatan pemahaman mahasiswa mengenai sistem basis data dengan menggunakan diagram Venn dan relasi sebagai alat bantu. Tujuan utama penelitian ini yaitu adanya peningkatan pemahaman mahasiswa mengenai sistem basis data dengan menggunakan operasi diagram Venn dan diagram relasi sehingga mahasiswa tidak kesulitan dalam menyelesaikan soal sistem basis data. Metode yang digunakan adalah penelitian pre eksperimen dengan desainnya yaitu one grup pretest-posttest design. Sampel yang digunakan berjumlah 45 mahasiswa semester 5 Jurusan Teknik Informatika tahun ajaran 2020/2021 Universitas Indraprasta PGRI. Instrumen yang dikumpulkan yaitu berupa hasil pretest dan posttest. Hasil persentase (P) bahwa peningkatan nilai pretest ke nilai posttest yaitu dari $64,33 \%$ menjadi $86,33 \%$ berdasarkan diagram Venn. Dari uji hipotesis statistik menggunakan uji Wilcoxon mendapatkan nilai sig $0,000<0,05$ yang menyimpulkan bahwa adanya peningkatan antara hasil pretest ke hasil posttest berdasarkan diagram Venn dibandingkan dengan diagram relasi. Oleh sebab itu, penulis menggambarkan bahwa rata-rata mahasiswa Unindra PGRI di semester 5 bisa memahami soal-soal basis data dengan cara menerapkan materi diagram Venn dan relasi serta hubungannya.
\end{abstract}

Kata Kunci : Diagram Venn, Relasi, Sistem Basis Data

\section{Abstract}

This research aims to improve the understanding of database system learning using Venn diagrams and relation diagrams. The first stage of the research was by conducting a pretest that contained the material, questions, and solutions using the Venn diagram and the relation diagram. The post-test stage was in the same way so that it can be seen an increase in student understanding of the database system by using Venn diagrams and relations as tools. The primary object of this research is to increase students' understanding of the database system using Venn diagram operations and relation diagrams to solve database system questions. The method used was pre-experimental research with the design of one group pretest and post-test design. The samples used were 45 students in semester 5 of the Informatics Engineering Department for the 2020/2021 academic year of Indraprasta University PGRI. The instruments collected were in the form of pretest and post-test results. The percentage result $(P)$ was that the pretest to post-test scores has increased from $64.33 \%$ to $86.33 \%$ based on the Venn diagram. The statistical hypothesis test using the Wilcoxon test obtained a sig value of $0.000<0.05$, which concluded that there was an increase between the pretest and post-test results based on the Venn diagram compared to the relation diagram. Therefore, the author describes that the average Unindra PGRI students in semester five can understand database questions by applying the Venn diagram material between relationships.

Key Words: Venn Diagrams, Relationships, Database Systems

\section{PENDAHULUAN}

Pendidikan formal kurikulum dapat dikatakan sebagai pondasi keberhasilan belajar dari pemahaman subjek masalah. Kurikulum sebagai program yang diselenggarakan oleh suatu lembaga pendidikan, digunakan sebagai pedoman oleh para pengajar demi tercapainya tujuan akhir pembelajaran. Menurut UndangUndang Dikti Nomor 12 Tahun 2012 tentang "Kurikulum pendidikan tinggi seperangkat rencana dan pengaturan 
mengenai tujuan, isi, dan bahan ajar serta cara yang digunakan sebagai pedoman penyelenggaraan kegiatan pembelajaran untuk mencapai tujuan Pendidikan Tinggi”[1].

Salah satu kurikulum pada jurusan Teknik Informatika Universitas Indraprasta PGRI yaitu mata kuliah Sistem Basis Data. Pada Rencana Pembelajaran Semester (RPS) Sistem Basis Data semester genap tahun 2019/2020 dengan pertemuan ke 5 dan 6 tentang Entity Relation Diagram (ERD), untuk menggambarkan relasi antar data [2]. Konsep data ini sangat mirip dengan materi tentang himpunan terutama pada relasi dan diagram Venn.

Berdasarkan pengamatan penulis, mahasiswa kurang memahami materi ERD terutama relasi data. Selain itu, dalam pembelajaran ERD kesulitan yang sering terjadi dikarenakan mahasiswa masih tidak paham ada kaitannya antara ERD, anggota himpunan, dan data. Diagram relasi berfungsi sebagai hubungan antara anggota himpunan [3], sedangkan diagram Venn merupakan hubungan antar himpunan dalam bentuk irisan dan gabungan [4]. Kedua diagram ini dapat dijadikan sebagai media alternatif pembelajaran pada materi ERD. Oleh karena itu, penulis menggunakan alat bantu proses pembelajaran dengan diagram Venn dan diagram relasi.

Penelitian sebelumnya tentang diagram Venn yaitu penelitian yang berjudul Media Smart Diagram Venn untuk Meningkatkan Pemahaman Konsep Siswa pada Materi Himpunan. Metode yang digunakan adalah tes di siklus I dan tes pada siklus II. Berdasarkan hasil penelitian yang ada dari kedua siklus didapatkan peningkatan hasil belajar [5].

Kemudian penelitian tentang diagram relasi, yaitu dengan Penerapan pembelajaran bauran (blended learning), ini terbukti dapat meningkatkan motivasi belajar siswa dalam mengikuti pembelajaran pada materi Relasi dan Fungsi. Penelitian ini menggunakan metode eksperimen dengan hasil yang sudah disebutkan di atas [6].

Namun penulis bukan hanya menggunakan metode eksperimen dan pengamatan dalam pemahaman materi diagram relasi dan diagram Venn, akan tetapi materi diagram relasi dan Venn bisa menjadi metode untuk alat ukur hasil pembelajaran sistem basis data mengenai materi ERD.

Tujuan penulis melakukan penelitian ini agar mahasiswa dapat memahami hubungan antar tabel pada sistem basis data, oleh karena itu untuk mengetahui peningkatan pemahaman mahasiswa maka penulis menggunakan pretest dan posttest mengenai soal-soal diagram Venn, diagram relasi dan basis data. Ditambah dengan pembuatan tabel relasinya, sehingga akan ditemukan bagaimana pengujian tersebut terdapat peningkatan pemahaman sistem basis data. Manfaat penelitian ini bagi penulis adalah dapat mengaplikasikan diagram Venn dan diagram relasi berdasarkan pada materi himpunan ke dalam mata kuliah sistem basis data terutama pada materi ERD. Hipotesis pada penelitian ini yaitu terdapat pengaruh diagram Venn dan diagram relasi dalam meningkatkan pemahaman sistem basis data.

Adapun teori yang mendukung dari materi himpunan adalah sebagai berikut:

Diagram Venn merupakan bentuk lain dari penyajian suatu himpunan dengan cara menggunakan gambar. Contoh :

$\mathrm{S}=\{0,1,2,3,4,5,6,7,8,9\}$

$X=\{1,2,4,5\} \quad Y=\{6,7,8\}$

Diagram Venn yang menunjukkan himpunan di atas dapat dilihat pada gambar berikut: 




Gambar 1. Contoh Diagram Venn

Contoh soal

1. diketahui gambar diagram Venn berikut.

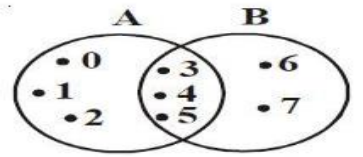

Gambar 2. Contoh Soal Diagram Venn

a) Pada gambar diagram Venn di atas manakah yang termasuk himpunan $\mathrm{A}$ dan $\mathrm{B}(\mathrm{A} \cap \mathrm{B})$ ?

Jawab : $(3,4,5)$

b) Tentukan seluruh anggota himpunan A?

Jawab : $(0,1,2,3,4,5)$

c) Tentukan seluruh anggota himpunan $\mathrm{B}$ ?

Jawab : $(3,4,5,6,7)$

d) Tentukan pula seluruh gabungan anggota $\mathrm{A}$ dan $\mathrm{B}$.

Jawab : $(0,1,2,3,4,5,6,7)$

Relasi antara A dan B (disebut relasi biner) adalah himpunan bagian dari A x B atau $\mathrm{R}$ $\subseteq(\mathrm{A} \times \mathrm{B})$. Jika $(\mathrm{a}, \mathrm{b}) \in \mathrm{R}$ digunakan notasi $a \mathrm{R} b$ yang artinya a dihubungkan dengan $\mathrm{b}$ oleh R. Jika $(\mathrm{a}, \mathrm{b}) \notin \mathrm{R}$ digunakan notasi a $\mathrm{R}$ $b$ yang artinya a tidak dihubungkan dengan b oleh R. Himpunan A disebut daerah asal (domain) dari $\mathrm{R}$ dan himpunan $\mathrm{B}$ disebut daerah hasil (Range) dari R [8]. Contoh : relasi himpunan $\mathrm{A}$ dan $\mathrm{B}$ dapat dilihat pada gambar di bawah ini:

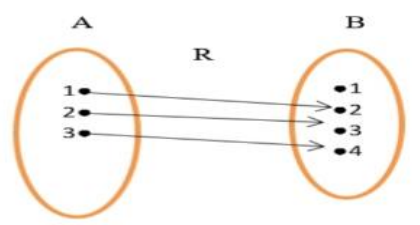

Sumber : [7]

Gambar 3. Contoh Relasi Dua Himpunan
Berdasarkan Gambar 1, domain $=\{1,2,3$,$\} ,$ range $=\{2,3,4\}$, maka relasi $\mathrm{R}=\{(1,2)$, $(2,3),(3,4)\}$.

\section{METODE}

Jenis penelitian yang akan diteliti adalah penelitian pre-eksperimen, metode dari penelitian ini menggunakan one grup pretest-posttest desaign. Berdasarkan desain dari penelitian ini digambarkan sebagai berikut [9]:

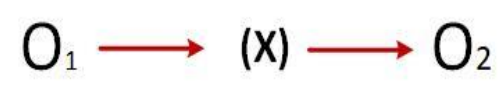

Sumber : [9]

\section{Gambar 4. One Grup Pretest-Postest Desain}

Keterangan :

$\mathrm{O}_{1}=$ Pretest pada kelas eksperimen

$\mathrm{X}=$ kelas yang mendapatkan perlakuan

$\mathrm{O}_{2}=$ Posttest pada kelas eksperimen

Sampel penelitian berjumlah 45 mahasiswa semester 5 pada jurusan Teknik Informatika tahun ajaran 2020/2021 Universitas Indraprasta PGRI. Rancangan kegiatan penelitian dapat dilihat pada Gambar berikut:

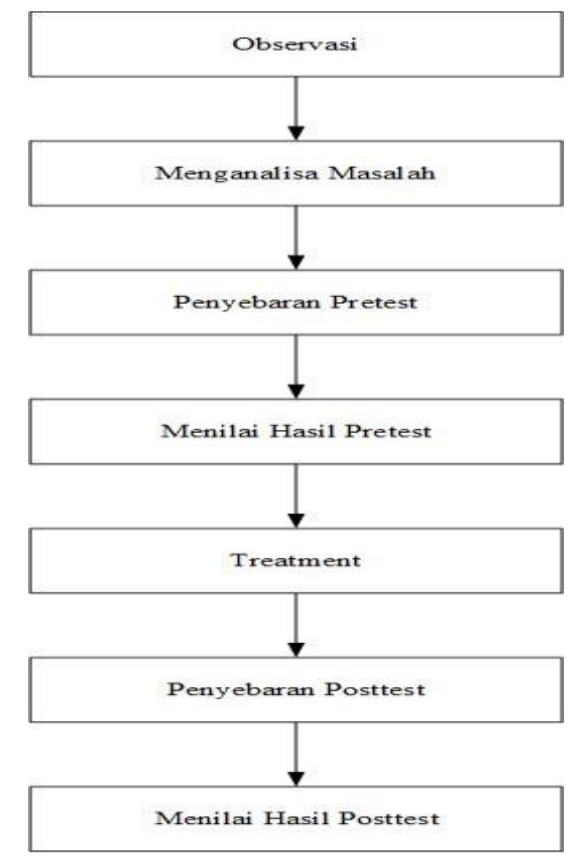

Gambar 5. Rancangan Kegiatan Penelitian 
Teknik pengumpulan data yaitu berupa data observasi, pretest dan postest. Sedangkan untuk analisis data yang akan digunakan dalam setiap data penelitian yang diambil yaitu menghitung persentase dari skor yang dicapai setiap mahasiswa dengan rumus:

$$
\mathrm{P}=\frac{\text { Skor rata-rata }}{\text { Skor maksimal }} \times 100 \%
$$

Kemudian hasil dari persentase tersebut berkualifikasi dengan pedoman acuan patokan (PAP) skala 5, berikut ini tabel kualifikasinya:

Tabel 1. Pedoman Acuan Patokan

\begin{tabular}{cc}
\hline Taraf Penguasaan & Kualifikasi \\
\hline $91 \%-100 \%$ & Memuaskan \\
$81 \%-90 \%$ & Baik \\
$71 \%-80 \%$ & Cukup \\
$61 \%-70 \%$ & Kurang \\
$<60 \%$ & Gagal \\
\hline & Sumber : [9]
\end{tabular}

Uji Prasyarat dalam menganalisis data berupa uji normalitas dengan menggunakan rumus uji normalitas Saphiro Wilk dengan bantuan SPSS 24, dikarenakan data sampel yang diambil kurang dari 50. Pada uji normalitas Saphiro Wilk dengan ketentuan data normal apabila nilai signifikansi $(P)$ lebih besar dari 0,05 $(P>0,05)$ [10]. Kemudian dilakukannya uji hipotesis menggunakan one sample t-test. Akan tetapi jika salah satu data pretest dan posttest tidak berdistribusi normal dan tidak homogen maka uji paired sampel Ttest diganti dengan menggunakan uji non-parametrik Wilcoxon. Kriteria penelitian ini apabila hasil uji Hipotesis nilai sig (2-tailed) lebih kecil dari nilai alpha/taraf signifikansi uji 0,05 maka Ha diterima, dan Ho ditolak.

\section{HASIL DAN PEMBAHASAN}

Berdasarkan hasil data pretest dan posttest dari soal-soal basis data yang di kombinasikan dengan materi himpunan mendapatkan hasil kenaikan nilai persentase yang cukup bagus. Hal ini terbukti dari nilai pretest mendapatkan
$64,33 \%$ sedangkan nilai posttesnya adalah 86,33\%. Sesuai dengan PAP (Pedoman Acuan Patokan) nilai pretest masuk ke dalam kualifikasi rentang 61\%-70\% dengan kategori kurang, sedangkan hasil posttest masuk ke rentang $81 \%$ - 90\% yaitu dengan kategori baik.

Berdasarkan uji prasyarat dalam menganalisis data berupa uji normalitas dengan menggunakan Saphiro Wilk dengan ketentuan data normal apabila nilai signifikansi $(P)$ lebih besar dari 0,05 $(P>0,05)$, didapatkan hasil data yang tidak berdistribusi normal yaitu dengan pretest nilai signifikansi $(P)$ 0,25 dan posttest signifikansinya $(P) \quad 0,00$ sehingga kedua data tersebut distribusi data yang tidak normal. Padahal jika menurut kriteria pengujian nilai $P$ harus lebih besar dari 0,05 akan tetapi hasil dari pretest dan posttestnya lebih kecil dari 0,05. Dikatakan data tidak normal, kemungkinan karena data yang didapatkan berasal dari persebaran data yang tidak normal [10].

Oleh karena itu, dilakukan uji Wilcoxon. Kriteria penelitian ini apabila hasil uji Hipotesis nilai sig (2-tailed) lebih kecil dari nilai alpha/taraf signifikansi uji 0,05 maka Ha diterima, dan Ho ditolak.

Tabel 2. Hasil Pengujian Uji Wilcoxon

\begin{tabular}{lllll}
\hline & \multicolumn{1}{c}{$\boldsymbol{N}$} & & $\begin{array}{l}\text { Mean } \\
\text { Rank }\end{array}$ & $\begin{array}{l}\text { Sum of } \\
\text { Ranks }\end{array}$ \\
\hline $\begin{array}{l}\text { pos } \\
\text { test }-\end{array}$ & $\begin{array}{l}\text { Negative } \\
\text { Ranks } \\
\text { pre }\end{array}$ & $0^{\mathrm{a}}$ & .00 & .00 \\
test & $\begin{array}{l}\text { Positive } \\
\text { Ranks } \\
\text { Ties }\end{array}$ & $44^{\mathrm{b}}$ & 22.50 & 990.00 \\
& & $1^{\mathrm{c}}$ & \\
\hline
\end{tabular}

\section{Interpretasi Data}

1. Negatif rank atau selisih (negatif) antara hasil pemahaman sistem basis data untuk pretest dan posttest adalah 0, baik itu pada nilai $N$, Mean Rank, maupun Sum of Rank. Nilai 0 ini menunjukkan tidak adanya penurunan (pengurangan) nilai pretest ke nilai posttest. 
2. Positif Rank atau selisih (positif) antara pemahaman sistem basis data untuk pretest dan posttest. Dimana dihasilkan 44 data positif $(N)$ yang artinya jumlah 44 mahasiswa mengalami peningkatan pemahaman sistem basis data dari nilai pretest ke nilai posttest. Mean Rank atau rata-rata peningkatan tersebut adalah 22,50, sedangkan jumlah ranking positif atau Sum of Rank adalah sebesar 990,00.

3. Ties adalah kesamaan hasil nilai pretest dan posttest terlihat di sini terdapat nilai Ties sebesar 1, sehingga dapat ditarik kesimpulan bahwa ada nilai yang sama antara hasil pretest dan posttest yaitu dengan jumlah 1 mahasiswa.

Tabel 3. Uji Statistik Uji Wilcoxon

\begin{tabular}{lr}
\hline & pos test - pre test \\
\hline$Z$ & $-5.792^{\mathrm{b}}$ \\
\hline Asymp. Sig. (2-tailed) & .000 \\
\hline \multicolumn{2}{c}{ Sumber : (Data olah SPSS 24, 2020) }
\end{tabular}

\section{Interpretasi Data Statistik}

Dasar pengambilan keputusan dalam uji Wilcoxon yaitu:

1. Jika nilai Asymp.Sig (2 tailed) lebih kecil dari $<0,05$, maka Ha diterima.

2. Sebaliknya, Jika nilai Asymp.Sig (2 tailed) lebih besar dari > 0,05, maka Ha ditolak.

Berdasarkan output yang ada, diketahui bahwa asymp. Sig (2 tailed) bernilai 0,000. Dikarenakan nilai 0,000 lebih kecil dari < 0,05, maka dapat disimpulkan bahwa $\mathrm{Ha}$ diterima [11]. Hal ini dapat diartikan ada peningkatan antara hasil pemahaman sistem basis data untuk pretest dan posttest, sehingga ada pengaruh Diagram Venn dan Relasi dalam Meningkatkan Pemahaman Sistem Basis Data.

Dilihat dari hasil yang ada, sesuai dengan penelitian yang menyatakan bahwa penerapan pembelajaran bauran (blended learning) ini terbukti dapat meningkatkan motivasi belajar siswa dalam mengikuti pembelajaran matematika pada materi relasi dan fungsi [6]. Penelitian tersebut menggunakan instrumen pretest-postest yang berupa data-data kuantitatif. Hal ini yang merupakan persamaan dengan penelitian ini yaitu sama-sama memakai instrumen pretest-postest pada materi relasi dan fungsi untuk mengukur tingkat pemahaman materi. Sedangkan perbedaannya yaitu pada media alat bantu dalam proses pembelajarannya.

Kemudian, jika dianalisis untuk setiap soal-soal posttest yaitu dengan model soal yang sama dengan pretest, akan tetapi soal posttest diberikan setelah diberikannya perlakuan menggunakan materi-materi himpunan yaitu diagram Venn dan relasi. Maka penulis masih menemukan kesalahan-kesalahan pada jawaban dari mahasiswa. Sebagai contoh, sampel hasil pekerjaan mahasiswa pada gambar berikut ini:
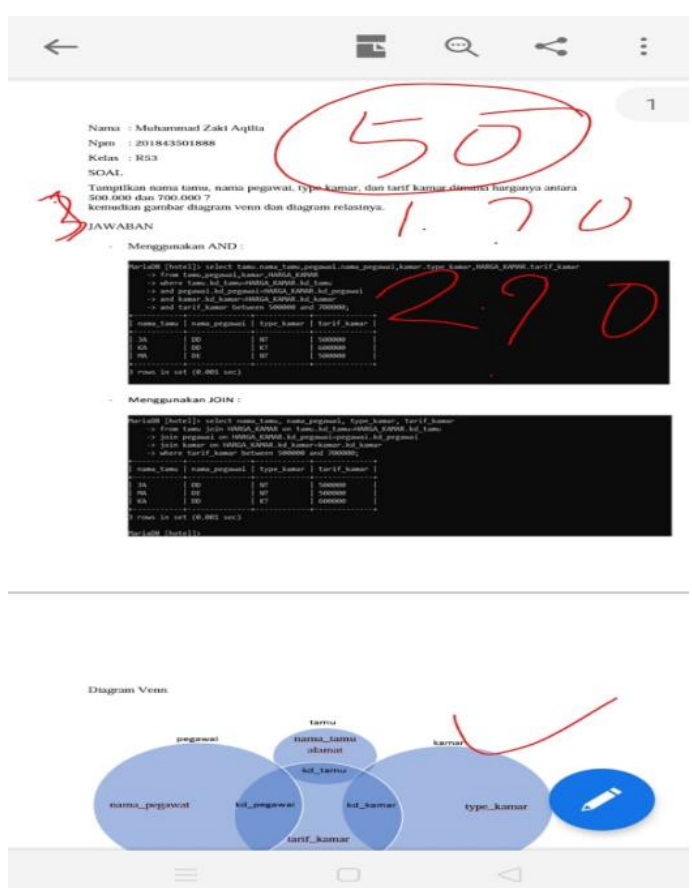

\section{Gambar 6. Hasil Jawaban Pretest Mahasiswa 1}

Berdasarkan pada gambar di atas bahwa hasil nilai yang didapat mahasiswa tersebut adalah 50 dikarenakan hanya menjawab di 
nomor 3 saja, sedangkan soal nomor 1 dan nomor 2 dia tidak menjawabnya. Oleh karena itu, poin nilai yang didapat sangatlah kecil, hal ini kemungkinan mahasiswa tersebut tidak memahami dan membaca dengan baik soal-soal yang ada.
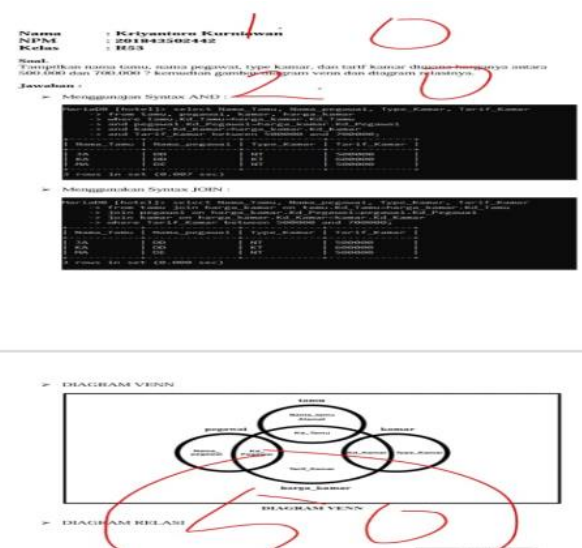

Gambar 7. Hasil Jawaban Pretest Mahasiswa 2

Hasil jawaban mahasiswa yang kedua juga hampir sama kasusnya dengan jawaban mahasiswa yang pertama, yaitu tidak mengerjakan soal di nomor 1 dan 2, kemungkinan mahasiswa menganggap bahwa soal-soal tersebut tidak ada kaitannya dengan basis data yang mereka kerjakan di nomor 3 padahal dengan menggambarkan diagram Venn dan diagram relasi dari anggota-anggota himpunan yang ada maka otomatis akan memahami tabel relasi dan isi dari basis data yang mereka buat.
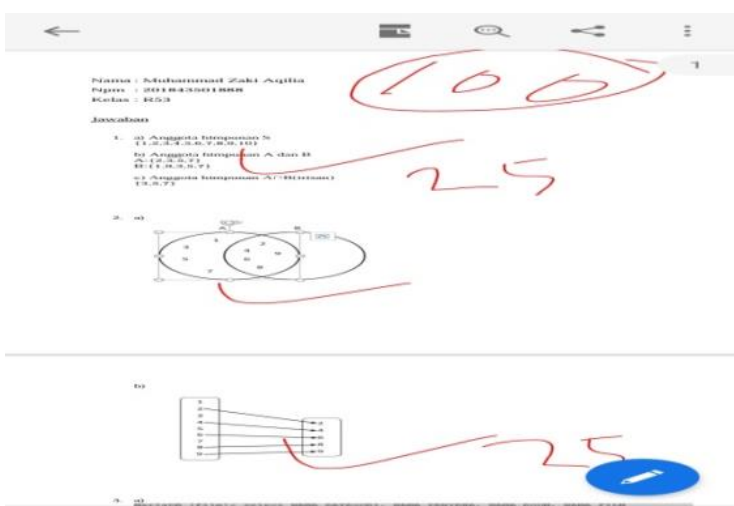

Gambar 8. Jawaban Posttest Mahasiswa 1
Berdasarkan gambar hasil postest mahasiswa 1 tampak mendapatkan nilai 100, hal ini membuktikan bahwa mahasiswa tersebut sudah bisa atau sudah paham dalam menggambarkan diagram relasi dan diagram Venn pada sebuah data dan pada anggota-anggota himpunan serta dapat mengaitkannya dengan penggambaran diagram Venn dan tabel relasi pada basis data yang mereka kerjakan di nomor 3.
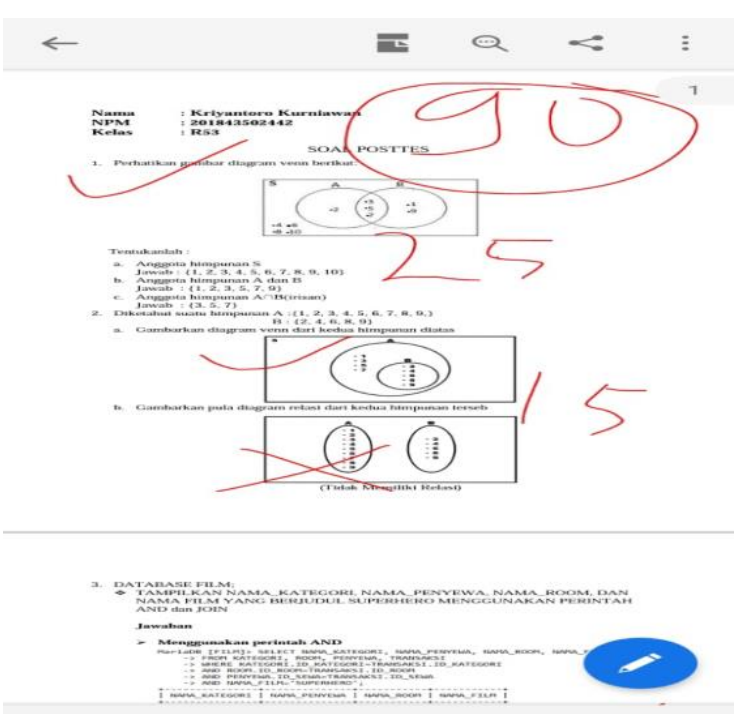

\section{Gambar 9. Jawaban Posttest Mahasiswa 2}

Berdasarkan hasil posttest salah satu mahasiswa, hampir memenuhi poin sempurna untuk setiap nomor penilaian. Hal ini terlihat pada nomor 1 mendapatkan poin 25 yang merupakan poin sempurna penilaian di nomor tersebut, dikarenakan mahasiswa tersebut bisa menjawab setiap pertanyaan di nomor 1 . Sedangkan di nomor 2, hanya mendapatkan poin 15 karena dalam menjawab pertanyaan di nomor 2 mahasiswa tersebut tidak menggambarkan adanya relasi yang berhubungan di antara himpunan $\mathrm{A}$ dan himpunan $\mathrm{B}$, terlihat di sini mahasiswa tersebut telah melakukan kekeliruan dalam menyatakan suatu relasi pada penggabungan himpunan A dan B. Lain halnya di soal nomor 3 , dalam membuat 
basis data dari soal dengan memakai and dan join menghasilkan data yang benar kemudian jika data tersebut digambarkan ke diagram Venn dan tabel relasi juga terlihat sudah bisa menggambarkan, oleh karena itu mahasiswa tersebut bisa mendapatkan poin nilai yg sempurna yaitu 50 poin di nomor 3 .

Untuk keseluruhan jawaban posttest, setelah diberikan perlakuan menggunakan alat bantu matematika menggunakan materi himpunan yaitu pada diagram Venn dan relasi, terdapat peningkatan pemahaman yang baik. Akan tetapi ada kesalahan yang masih sering dilakukan mahasiswa dalam menggambarkan relasi antar anggota himpunan yang ada pada soal posttest di nomor 2 bagian b. Mereka salah menafsirkan bagaimana relasi atau hubungan yang mengaitkan kedua anggota suatu himpunan. Sedangkan dalam penggambaran diagram Venn mereka sangat mahir dan memahaminya.

Dapat dikatakan mahasiswa hanya memperhatikan relasi antar himpunan tetapi tidak melihat relasi setiap anggotaanggotanya. Dengan kata lain mahasiswa kurang memahami apa fungsi dari data di dalam basis data. Oleh karena itu, penulis perlu melanjutkan penelitian dengan teori diagram relasi lebih mendalam untuk meningkatkan pemahaman mahasiswa terhadap relasi data dalam basis data.

\section{SIMPULAN}

Berdasarkan analisa dari diagram Venn dan diagram relasi, bahwa mahasiswa hanya memperhatikan relasi antar himpunan, maka penulis dapat menyimpulkan yaitu hasil persentase $(P)$ menghasilkan peningkatan pemahaman dengan nilai pretest ke nilai posttest yaitu dari $64,33 \%$ menjadi $86,33 \%$, dari uji hipotesis statistik menggunakan uji Wilcoxon mendapatkan nilai sig $0,000<$ 0,05 yang menyimpulkan bahwa adanya peningkatan antara hasil pretest ke hasil posttest, sehingga terdapat pengaruh diagram Venn dan diagram relasi dalam meningkatkan pemahaman sistem basis data. Oleh karena itu, walaupun terjadi peningkatan, setelah dianalisis setiap soalsoal posttest mahasiswa hanya memperhatikan relasi antar himpunan tetapi tidak melihat relasi setiap anggotaanggotanya. Dengan kata lain mahasiswa kurang memahami apa fungsi dari data di dalam basis data.

\section{DAFTAR PUSTAKA}

[1] Pemerintah Republik Indonesia. "UU No 12 Tahun 2012 tentang Pendidikan Tinggi”. Republik Indones., no. May 2014, p. 32, 2012.

[2] D. Edi dan S. Betshani. "Analisis Data dengan Menggunakan ERD dan Model Konseptual Data Warehouse". J. Inform., vol. 5, no. 1, pp. 71-85, 2012.

[3] S. Julaeha, et al.. "PEMETAAN TABEL RELATIONSHIP DALAM VISUALISASI". vol. 5, no. 2, pp. 126-133, 2020.

[4] A. Aristia, A. Andinasari, dan T. D. Nopriyanti. "Kemampuan Pemahaman Konsep Matematika Melalui Model Learning Cycle 5E Berbantu Simulasi Diagram Venn". Indiktika J. Inov. Pendidik. Mat., vol. 1, no. 2, p. 190, 2019, doi: 10.31851/indiktika.v1i2.3213.

[5] T. R. Murniasih, R. D. Ferdiani, dan T. Fayeldi. "Media Smart Diagram Venn untuk Meningkatkan Pemahaman Konsep Siswa pada Materi Himpunan". Math Didact. J. Pendidik. Mat., vol. 2, no. 2, pp. 70 76, 2016, doi: 10.33654/math.v2i2.30.

[6] L. R. Hima. "Pengaruh Pembelajaran Bauran (Blended Learning) terhadap Motivasi Siswa pada Materi Relasi dan Fungsi”. JIPMat, vol. 2, no. 1, 2017 , 
10.26877/jipmat.v2i1.1479.

[7] M. Nuh. Matematika Studi dan Pengajaran. Matematika untuk SMP/MTs Kelas VIII Semester 2. Jakarta: Kementrian Pendidikan dan Kebudayaan, 2014. [Online]. Tersedia: http://repositori.kemdikbud.go.id/696 2/1/buku\%20guru\%20matematika.pd $\mathrm{f}$

[8] D. Puspita dan Erlin. "Sistem Silsilah Keturunan Menggunakan Metode Komposisi Relasi". SATIN - Sains dan Teknol. Inf., vol. 2, no. 2, pp. 916, 2013.

[9] S. Duwila, I. Hamid, dan A. Jalal. "Peningkatan

Kemampuan Representasi Matematis Siswa SMP pada Materi Diagram Venn melalui Pendekatan Realistic Matematis
Education". Delta-Pi J. Mat. dan Pendidik. Mat., vol. 8, no. 1, pp. 6480, 2019, doi: 10.33387/dpi.v8i1.1366.

[10] H. Rosiyanti. "Implementasi Pendekatan Pembelajaran Konstruktivisme terhadap Pemahaman Konsep Matematika Mahasiswa Materi Transformasi Linier". FIBONACCI J. Pendidik. Mat. dan Mat., vol. 1, no. 2, p. 25, 2015.

[11] D. Anastasya, S. R. Dewi, dan N. P. Murnaka. "Pengaruh Games Memorize Card terhadap Hasil Belajar Siswa pada Operasi Hitung Bilangan". Kreano, J. Mat. Kreat., vol. 6, no. 2, p. 164, 2015, doi: 10.15294/kreano.v6i2.5010. 